\title{
Greening Capitalism? A Marxist Critique of Carbon Markets
}

\section{Steffen Böhm}

University of Essex, UK

\section{Maria Ceci Misoczky}

Federal University of Rio Grande do Sul, Brazil

\author{
Sandra Moog
}

University of Essex, UK

\begin{abstract}
Climate change is increasingly being recognized as a serious threat to dominant modes of social organization, inspiring suggestions that capitalism itself needs to be transformed if we are to 'decarbonize' the global economy. Since the Kyoto Protocol in 1997, carbon markets have emerged as the main politico-economic tools in global efforts to address climate change. Newell and Paterson (2010) have recently claimed that the embrace of carbon markets by financial and political elites constitutes a possible first step towards the transformation of current modes of capitalist organization into a new form of greener, more sustainable 'climate capitalism.' In this paper, we argue that the institutionalization of carbon markets does not, in fact, represent a move towards the radical transformation of capitalism, but is better understood as the most recent expression of ongoing trends of ecological commodification and expropriation, driving familiar processes of uneven and crisis-prone development. In this paper, we review four critical Marxist concepts: metabolic rift (Foster, 1999); capitalism as world ecology (Moore, 20I la); uneven development and accumulation through dispossession (Harvey, 2003, 2006); and sub-imperialism (Marini, 1972, 1977), developing a framework for a Marxist analysis of carbon markets. Our analysis shows that carbon markets form part of a longer historical development of global capitalism and its relation to nature. Carbon markets, we argue, serve as creative new modes of accumulation, but are unlikely to transform capitalist dynamics in ways that might foster a more sustainable global economy. Our analysis also elucidates, in particular, the role that carbon markets play in exacerbating uneven development within the Global South, as elites in emerging economies leverage carbon market financing to pursue new strategies of sub-imperial expansion.
\end{abstract}

\section{Keywords}

Brazil, BRICS, capitalism, carbon markets, climate change, Global South, Marxism, political economy

Corresponding author:

Steffen Böhm, Essex Business School, University of Essex, Wivenhoe Park, Colchester C04 3SQ, UK

Email: steffen@essex.ac.uk 


\section{Introduction}

Environmental, anti-colonial and anti-imperialist movements, pointing to capitalism's immense negative impacts on the environment, have long argued that the global economy needs to be radically transformed (Banerjee, 2003; Esteva, 1987; Guha, 1988; Shiva, 2005; Korten, 2006; Pouchepadass, 1995; Misoczky, 2011). But these activists and theorists have recently been joined by a chorus of more mainstream voices, expressing surprisingly similar sentiments. Business guru Haque (2011), for example, insists that a 'new capitalist manifesto' is needed, in order to make capitalist development and growth more socially just and environmentally sustainable, while Harvard Business School's Porter and Kramer concur that 'the moment for a new conception of capitalism is now' (2011, p. 62). Such calls by leading business commentators would appear to suggest that even mainstream thinkers now recognize the seriousness of the manifold environmental crises confronting humanity, and the inadequacy of traditional capitalist modes of organization in the face of these challenges.

In their recent book, Climate Capitalism, Newell and Paterson (2010) claim that, in response to rising social concerns about climate change, fledgling attempts to reorganize capitalism are, in fact, already under way. Pointing to the creation of new governance mechanisms such as carbon markets, and the increasing commitment of political and financial elites to these policy tools, they claim we are witnessing the emergence of a new paradigm, which they call 'climate capitalism': the political attempt to decarbonize the global economy while simultaneously ensuring continued economic growth (Newell \& Paterson, 2010, p. 1). But, do pervasive new discourses about 'sustainable development' and the 'green economy,' and the concrete new politico-economic tools that are being developed to address problems like climate change, actually constitute the first steps towards a radical transformation of capitalism?

Calls for 'sustainable development' first gathered momentum with the publication of the Brundtland Report (World Commission on Environment and Development, 1987) in the run-up to the UNCED 'Earth Summit', which was held in Rio de Janeiro in 1992. With Western economies, and particularly multinational companies, coming under pressure for their poor environmental records, the Rio Summit was designed to define responses to humanity's multiple environmental crises, especially the challenge posed by climate change. While many environmental movements had called, at Rio, for a restructuring of the global economy to ameliorate inequalities between the Global North and Global South, and for a fundamental reconsideration of the growth mantra of capitalist development, the main outcome of the Earth Summit was, on the contrary, the institutionalization of neoliberal approaches to sustainable development (Chatterjee \& Finger, 1994; Bernstein, 2002; Bruno \& Karliner, 2002). The liberal norm-complex articulated in the Rio Declaration, and institutionalized in the approaches to environmental governance that have dominated in the years since Rio, has been based upon two fundamental assumptions, 1) that free trade regimes and high economic growth rates are not only compatible with, but are important preconditions for, environmental sustainability, and, 2) that market-based tools are the most appropriate instruments to apply in efforts to achieve that goal (Bernstein, 2002, p. 101). In line with these principles, carbon markets, introduced in the 1997 Kyoto Protocol, have been embraced throughout the last few decades as a preferred politico-economic tool for tackling climate change. Support for market-based approaches to global environmental problems was reaffirmed in the conference documents issued at the UNCED Rio+20 conference in 2012, which see governance mechanisms such as carbon markets as key components of a promising new 'green economy' (UNCED, 2012; Foster, 2012).

Despite such expressions of optimism, on the part of observers like Newell and Paterson and international negotiators at Rio +20 , however, the sheer complexity of carbon markets and the 
wide-ranging social implications of their application have led to an explosion of often heated exchanges between academics, policy analysts and climate activists about the effectiveness of these policy instruments, and about their social, economic and environmental impacts (e.g. Michaelowa \& Dutschke, 2000; Stowell, 2005; Yamin, 2005; Lohmann, 2006; Newell \& Paterson, 2010; Böhm \& Dabhi, 2011; Michaelowa, 2011; Newell, 2012). Many authors see carbon markets as a viable tool for dealing with climate change, pointing to the need to create economic (i.e. profit) incentives in order to generate the vast sums of investment needed to decarbonize the global economy (Newell \& Paterson, 2010, p. 104). While it is often acknowledged that such markets have had some 'teething problems,' these authors argue that such problems can, nevertheless, be overcome through better design (Michaelowa, 2011), and through collaboration amongst local and global governmental agencies, as well as NGOs and other private actors (e.g. Pinkse \& Kolk, 2012).

There are, however, other critics who see these problems as symptoms of a fundamental ineffectiveness of carbon markets as a policy tool, and, more broadly, of the failure of neoliberal, market-based environmentalism to address problems such as climate change. One of the most outspoken critics has been Lohmann (2006, 2008a, 2008b, 2009a, 2009b, 2010) who has stressed the ineffectiveness and corrupt development of carbon markets, as well as their negative social, economic and environmental outcomes. In a similar vein, Whiteman, Dorsey and Wittneben (2010) have argued that these kinds of market-based systems often privilege elite groups in developing countries, while Bond (2007) has explored how carbon markets create perverse incentives for exploiting the under-privileged. Bachram (2004), identifies this as the 'neo-colonial' dimension of carbon markets, while Sullivan (2010) and Heartfield (2008) argue that carbon markets should, in fact, be seen as part of a broader set of 'green economy' discourses and practices which are currently facilitating the expansion of capitalist accumulation through the capture, pricing and monetization of ecosystem services and other environmental goods (see also, Mueller \& Passadakis, 2008; Foti, 2009).

We will discuss some of these critiques of carbon markets in more detail in the next section of this paper. What is often missing in such accounts, however, we will argue, is a sustained positioning of these politico-economic tools within the broader history of global capitalist development and its relation to nature. In this article, we develop a synthetic Marxist frame of analysis, in order to explore the following question: do carbon markets, designed to help to implement the 'sustainable development' agenda at a global level, constitute a move toward the transformation of contemporary modes of capitalism? Or are they better understood as a part of a continuous trajectory of capitalist dynamics, structuring human relations and the natural environment in familiar ways?

We look to Marxist theory in our efforts to understand capital's current attempts to 'green' itself. As Marx and Engels (1975) argued long ago, the dynamics of capitalism constantly tend to propel economic processes beyond the limits of controllable growth. As a consequence, major crises mark the historical advance of capitalist accumulation - as we have seen in the recent global financial crisis (Harvey, 2010). These include environmental crises that result from capitalism's persistent tendency to deplete natural resources and generate externalities, i.e. environmental costs that are 'dumped' onto nature and society without being accounted for within the capitalist processes of valuation, production and exchange (O’Connor, 1988, 1998; Foster 1999). As capitalism reforms and changes itself, however, new configurations of accumulation and legitimation are revealed (Marx \& Engels, 1964; Marx, 1976, 1981), including new relations to nature and the environment (Moore, 2010).

Thus far, capitalism has shown a capacity to recover from the economic and environmental crises it has produced. This resilience may well be the reason why some people have come to believe that effective solutions for combatting climate change can only come through a process of 
capitalist reform, such as the introduction of new market mechanisms. We argue, however, that, even if a decarbonized capitalist 'green economy' were possible, such an economy would be characterized by uneven growth and disparities of income, and by the unequal distribution of economic, social and environmental risks that global markets produce. We put forward this argument by reviewing four key Marxist approaches, provided by Foster (1999, 2000, 2002), Moore (2010, 2011a, 2011b), Harvey $(2003,2006)$ and Marini $(1977,2005)$. We employ the analytical tools of these writers in order to assess, 1) to what extent carbon markets form part of broader trends in the historical development of capitalism, 2) how carbon markets function within the contemporary regime of capitalist accumulation, 3) what effects they have on ecological transformations around the world, and 4) what role countries and elites in the Global South are playing in the contemporary emergence of what Newell \& Paterson (2010) call 'climate capitalism'.

\section{Carbon Markets and Their Critics}

A consensus, however fragile it might be, seems to have been reached on how to mitigate the most dramatic consequences of climate change, 'a consensus that is now largely shared by most political elites from a variety of positions, business leaders, activists and the scientific community' (Swyngedouw, 2010, p. 215). This consensus, which Newell and Paterson call 'climate capitalism' (2010), is a new regime of capitalist organization whose task is to 'decarbonize' and 'green' the economy with minimal disruption to patterns of economic growth and expansion of the global economy. The key politico-economic tool at the heart of 'climate capitalism' is carbon trading.

While the idea of emissions trading mechanisms goes back more than three decades (see Tietenberg, 2006), it was the 1997 Kyoto Protocol that first established a global framework for carbon markets. The most important political milestone in international climate politics to date, the Kyoto Protocol set legally binding emissions targets for the most industrialized countries, sometimes referred to collectively as the 'Global North.' The idea of emissions trading mechanisms was introduced into the Kyoto process by the U.S. delegation. In line with its dominant neoliberal politico-economic approach in the early 1990s, the U.S. delegation argued that only market mechanisms could achieve emission reductions in an efficient and cost-effective way (Tietenberg, 2006). In an attempt to bring the U.S. on board, the key negotiating countries reluctantly signed up to the introduction of carbon markets, namely carbon trading (also called 'cap and trade') and carbon offsetting (Abate, 2005). Although the U.S. ultimately refused to ratify the treaty, these market mechanisms nevertheless became a key element of the Kyoto process.

'Cap and trade,' briefly, is a market mechanism primarily designed for the industrialized countries of the Global North, in order to help them decrease their carbon emissions. The underlying assumption of this system is that emissions reduction can be achieved at the lowest possible cost by, first, quantifying the emissions that are caused by industrial activities; second, setting a cap on all greenhouse gas (GHG) emissions; and, third, incentivizing companies and entire industries to make decisions on how to meet their caps in the cheapest possible way. The EU Emissions Trading System (EU-ETS), for example, is the world's largest existing 'cap and trade' system, involving 15 EU countries and covering more than 10,000 industrial installations. Its aim is to reduce the EU's carbon emissions by $8 \%$ below 1990 levels during the first Kyoto compliance period, between 2008 and 2012 (Böhm \& Dabhi, 2009, p. 12). The EU-ETS works by setting 'caps', maximum allowances for GHG emissions, for individual EU countries; those countries, in turn, allocate allowances to their largest carbon-emitting operations, such as power stations. If a power station emits more than its carbon allowance, it will have to buy allowances from other polluters, in order to avoid heavy punitive fines. Alternatively, if the company finds it relatively easy and cheap to 
invest in 'green technologies' that reduce its carbon emissions below the set cap, then it can sell carbon allowances on the open market, generating income.

Besides the cap and trade mechanism, the Kyoto Protocol also provides a framework for the introduction of the Clean Development Mechanism (CDM). The CDM is a carbon offset market, enabling the most developed industrial countries and their companies to buy carbon credits from so-called 'clean development' projects located in the Global South, i.e., projects that supposedly represent 'cleaner' forms of development, in terms of their carbon footprints, which are based in those developing countries that are not legally bound to reduce their own carbon emissions under the Kyoto Protocol. The CDM was conceived in order to provide 'flexibility', in terms of how industrialized or developed countries can meet their Kyoto commitments (Newell \& Paterson, 2010, p. 80-82). In the words of the UN Framework Convention on Climate Change, it 'allows emission-reduction (or emission removal) projects in developing countries to earn certified emission reduction (CER) credits, each equivalent to one ton of $\mathrm{CO}_{2}$ (UNFCCC, 2010). These CERs can then be traded and sold, and they can be used by industrialized countries to meet part of their emission reduction targets under the Kyoto Protocol. Given that it is often much cheaper and easier to fund new development projects in the Global South than to cut emissions in the Global North, Northern participation in the CDM has proven particularly popular, suggesting that industrialized countries and their companies prefer to offset their emissions, rather than to reduce them at their source (Dale, 2008). This is precisely the 'flexibility' that was intended when this mechanism was introduced into the 1997 Kyoto Protocol, as the US delegation, in particular, was very concerned that their industrial heartland would be threatened by increased costs imposed by reduction targets, and sought to include 'flexible' means of avoiding these costs within the Kyoto agreements (Newell \& Paterson, 2010, p. 79).

Parallel to the UN-administered CDM process, a voluntary offset market (VOM) has developed as well, enabling individuals, companies and other organizations that are not part of formal emission reduction systems to attempt to reduce their climate impact by buying 'offsets', or 'carbon credits.' The underlying principle of both the CDM and VOM is the same: they are both seen as 'win-win' solutions, enabling Northern countries and companies to meet their legally binding or voluntary emissions targets relatively cheaply by investing in Southern countries where costs would normally be lower, while allegedly providing the Global South with much needed investments in 'clean technologies.' Participation in the VOM, for example, has recently allowed Land Rover, a major UK car manufacturer, to claim that all of its new vehicles are 'carbon neutral' (Land Rover, 2011). It is able to make such a claim because it offsets the carbon emissions of its entire manufacturing processes by working with ClimateCare, one of the largest carbon consultancy businesses in the world. On Land Rover's behalf, ClimateCare invests in projects such as high pressure biomass boilers in Argentina or wind farms in China (ClimateCare, 2011). The logic is that these projects should enable Southern countries to develop, while making sure that they are as 'sustainable' and 'clean' as possible, i.e. producing less carbon emissions than 'business as usual' options.

Carbon offsetting has been a mushrooming business. According to the current CDM statistics, more than $5600 \mathrm{CDM}$ projects are in the pipeline, of which more than 4600 are already registered; these projects are expected to produce more than 2 billion Certified Emission Reduction Units (CERs) by 2012 (UNFCCC, 2012). Between 2002 and 2010, the value of transactions in the primary CDM market, according to World Bank calculations, was approximately $\$ 27$ billion (although actual financial flows by 2010 were actually much lower, around $\$ 5.4$ billion, as the majority of transactions included in those figures were 'forward purchasing agreements,' with payment on delivery at a future date) (World Bank, 2011, p. 27). Significant parts of these funds 
go towards transaction costs, such as consultancy, banking and other service fees; nevertheless, the CDM has generated significant funds, which have been invested in the Global South. Equally successful, the VOM doubled in size in 2008 alone, and was at the time worth about $\$ 700$ million (US Department of Environment, 2011a, 2011b). Carbon offsetting is projected to become a multi-billion dollar industry over the next few years, if global agreements can continue to be reached regarding how to curb carbon emissions beyond the Kyoto commitment period, which ends in 2012 (Bloomberg New Energy Finance, 2010). Yet, even if no post-Kyoto treaty is agreed, this newly emerging carbon economy is here to stay, with the voluntary offset market alone projected to triple by 2020 (ibid.).

Ever since they first began to appear on the political agenda of international climate negotiations in the 1990s, carbon markets have been fiercely criticized. Some commentators have called the VOM, for example, the 'wild west' of carbon trading, because extraordinary profit potentials have attracted many new market entrants into a field in which there is often no governmental scrutiny or industry self-regulation (Fahrenthold \& Mufson, 2007). In response to these accusations, the industry, often in conjunction with NGOs, has established a range of different standards, such as the Gold Standard and Social Carbon Standard, which claim to have raised the quality and legitimacy of such 'verified' offsetting projects (Schlup, 2005; Newell \& Paterson, 2010, pp. 120-121). Though these industry-driven self-regulatory standards aim to emulate the fairly strict quality controls that are obligatory for the more heavily controlled CDM (governed by the United Nations Framework Convention on Climate Change (UNFCCC), critics point out that the broader effect of these schemes is to encourage consumers in the North to feel that they can avoid taking responsibility for their own consumption, and for the carbon emissions they produce, by pushing off responsibility for 'clean development' onto other people, elsewhere on the planet (Smith, 2008).

Europe's EU-ETS cap and trade scheme has had its fair share of problems as well. When it was first introduced, the EU, in response to intense business lobbying, made very generous initial carbon allocations to the most polluting industries (Reuters, 2007; Giddens, 2009; Lohmann, 2008b, $2009 b$ ). This allocation constituted, in essence, a windfall gift of 'rights to pollute' for big corporations, and led ultimately to a market depreciation in the value of carbon credits. The scheme therefore failed to provide compelling incentives for business to invest in greener technologies (Reuters, 2007; Newell \& Paterson, 2010; Carbon Trade Watch, 2011). Moreover, while many EU countries may now appear to be on course to meet their legally binding Kyoto emissions reduction targets, they have, in fact, only managed to stay on target by buying carbon offsetting credits from developing countries (Reyes, 2011). Thus, rather than cutting their own carbon emissions at home, the EU-ETS has encouraged companies to offset their obligations by paying poorer countries for the implementation of CDM projects. This has led to accusations that the EU is essentially 'exporting' its legally binding carbon reductions (ibid.).

The Clean Development Mechanism has been criticized on a number of different counts. One of the most outspoken critics of the CDM has been Lohmann (2006, 2008a, 2008b, 2009a, 2009b, 2010). He maintains that 'even the most staunch supporters' of carbon markets 'were commonly admitting by 2007 that a quarter (Sutter \& Parreño, 2007), a half (Schlup, 2005) or more of all CDM projects were business as usual' (Lohmann, 2009b, p. 510). That is, many 'clean development' projects are not 'additional,' which is the jargon used to stipulate the strict requirement that GHG emissions are lower after the implementation of the CDM project, compared to the emissions that would have occurred without CDM financing. As a result, Lohmann (2009b, p. 510) argues, the CDM market, rather than genuinely taking carbon out of the atmosphere, often simply creates additional profit opportunities for a range of existing investment and infrastructure projects. This includes environmentally destructive projects such as dams which were already in planning, or in 
construction, long before the beginning of the first Kyoto commitment period in 2008. Lohmann (2009b, p. 510) concludes that many of these projects are actually enabling increases in fossil fuel emissions, both in the most industrialized nations and in the Global South, and are thus having a net negative effect on climate change mitigation (see also Lohmann, 2006, p. 148). In this way, carbon markets can be seen as effectively hindering the development of more sustainable and resilient local practices (Lohmann, 2009b, p. 513).

A number of researchers have recently argued, moreover, that rather than encouraging 'greener' modes of development in the South, CDM funding frequently subsidizes polluting industries there. According to Smith (2008, p. 3), 'CDM financing has entrenched dirty development [in the South] by acting as a financial subsidy for big industrial polluters such as chemical factories, coal fired power stations and pulp and paper mills'. In part, this is because Designated National Authorities (DNAs), which is the CDM jargon for those institutions in Southern countries that are supposed to monitor their national CDM projects, act more like business development agencies than like watchdogs that have the wider public good in view (Gilbertson, 2009; Cabello, 2009). Ghosh and Sahu (2011) concur, concluding that the CDM frequently subsidizes and legitimizes corporate pollution. Even EU Climate Action Commissioner Connie Hedegaard has recently admitted that many of these CDM projects have a 'total lack of environmental integrity' (Reyes, 2011, p. 1).

The claim that the CDM has been beneficial in terms of 'technology transfer' has also been criticized. While optimistic analyses show that some technology transfer from North to South has taken place (e.g. involving industrial gas projects, see Seres, 2008), critics argue that this has often involved fairly simple, pre-existing technologies, which have been transferred in a very inefficient manner (Wara, 2007). Lohmann (2009c), however, goes further, arguing that

'technology transfer' continues to carry the connotation, as it always has, of moving Northern technology into a 'technology-deprived' area in the South. In practice, this typically plays out in the degradation, skewing or destruction of one set of technologies in favor of another. (Lohmann, 2009c, p. 1070)

This view is supported by a number of the cases presented in Böhm and Dabhi (2009). Gilbertson (2009), for example, reports on a CDM biomass power generation project in Thailand that uses rice husk as raw (renewable) material. While local industrial elites call this rice husk 'waste,' peasants in the area have been using it as natural fertilizer and for brick manufacturing for generations. However, now that profits can be made from burning the rice husk for electricity generation, creating 'carbon credits' that can be sold to Northern countries and companies, this renewable technology/ resource has become a valuable (overpriced) commodity. As a result, peasants now have to buy chemical fertilizers, which increase their cost base. This has an indirect impact on climate change, since the production of these fertilizers itself generates carbon emissions. Additionally, Gilbertson (2009) reports that there have been health (e.g. respiratory problems) and environmental hazards (e.g. dumping of waste ash) produced by this new 'clean development' project. This is just one example of the type of evidence that is emerging in the literature, which suggests that carbon markets such as the CDM often have negative effects on both the environment and on poorer populations in the Global South.

While it is important to point out that the CDM is not intended to eradicate injustice and poverty in the South, the CDM is meant to be explicitly geared towards sustainable development goals (Grubb et al., 1999). It is for this reason that critics lament the fact that social development is rarely at the heart of such projects. Sirohi (2007, p. 91), for example, reports that CDM projects are, in fact, 'not contributing to rural poverty alleviation to any notable extent'. Her research, on the contrary indicates that 'nearly all the projects have a business orientation and are not directed to the 
development of rural poor' (ibid.; see also Olsen, 2007). Even supporters of the carbon market idea, like Sutter and Parreño, have been highly critical of the sustainability record of the CDM. Writing in 2007, they reported that there were 'currently no UNFCCC registered CDM projects that are likely to fulfill the Kyoto Protocol's twofold objective of simultaneously delivering greenhouse gas (GHG) emission reduction and contributing to sustainable development' (Sutter \& Parreño, 2007, p. 75).

Reviewing the literature, it appears that many authors see carbon markets as characterized by a series of design flaws and pervasive weaknesses in implementation. While some maintain that these tools can be reformed to achieve their ultimate aim of decarbonizing the global economy (e.g. Michaelowa, 2011; Wara, 2007), other critics see these market design flaws, or failures, as an inherent part of the broader political economy of contemporary climate change mitigation efforts (e.g. Lohmann, 2006; Bond, 2007; Böhm \& Dabhi, 2009; Bachram, 2004; Bäckstrand and Lövbrand, 2006, Bumpus and Liverman, 2008). The political economic orientation of contemporary carbon markets, these authors concur, is not primarily geared towards cutting GHG emissions as quickly as possible, but, on the contrary, towards preserving the interests of fossil fuel dependent countries and their multinational companies, particularly those in fossil fuel energy and heavy industry sectors. What we have learned from these critiques of carbon markets is that the commodification of carbon sinks, and the transfer of various forms of ecological value through carbon markets to elites in both the South and the North, represent an extension of power by capital; they entail an empowerment of dominant countries and elite groups vis-à-vis subordinates across the globe and an exacerbation of global inequities. What is often missing in such critiques of carbon markets, however, is a sustained and in-depth discussion of exactly how these new politicoeconomic tools (carbon markets) can be analyzed as part of the broader historical development of capitalism, including the specific relations between North and South, as well as between society, economy and nature.

To provide this broader historical perspective, in the next section we review four Marxist analytical approaches, tracing recent efforts to understand contemporary ecological politics within a broader framework of capitalist crisis, the changing structure of the international division of labor, and the dialectical co-development of capitalist regimes of accumulation and forms of transformation of the natural environment. Based on works by Foster (1999, 2000), Moore (2011a, 2011b), Harvey $(2003,2006)$ and Marini $(1972,1977,2005)$, we then, in the following section, build a broader framework for the analysis of capitalist re-organization in the age of climate change. Returning to the questions with which we opened this article above, we ask whether it makes sense, given current trends in the historic evolution of carbon markets, to understand these markets as part of a fundamental transformation of capitalism: a new 'concept of capitalism' (Porter \& Kramer, 2011), or evidence of the rise of a new era of 'climate capitalism' (Newell \& Paterson, 2010). Or, on the contrary, given that carbon markets are proving to be such weak instruments, in terms of their effects on net global carbon emissions and in terms of their ability to foster a broader transition to more ecologically and socially sustainable development, does it perhaps make more sense to understand these mechanisms as part of a new phase of intensified ecological exploitation and uneven capitalist growth?

\section{Capitalism and its Relation to Nature: Four Marxist Approaches}

In this section we review a set of contemporary Marxist approaches, advocating their articulation as a historico-dialectical reference for the critical understanding of carbon markets. In the 
following subsections, we present a brief overview of: (1) the metabolic rift theory, proposed by John Bellamy Foster, (2) Jason Moore's conception of capitalism as world-ecology, (3) uneven development and accumulation by dispossession, as conceptualized by David Harvey, and (4) Ruy Mauro Marini's concept of sub-imperialism. Writers working in these traditions have recently attempted to integrate an ecological dimension into the understanding of capitalist crises, accumulation regimes, and the dialectical development of new configurations of the international division of labor. Combining insights from these various strands of recent Marxist theory, we argue, can provide a useful framework for understanding the place of carbon markets within contemporary capitalism, and specifically their role in ongoing reconfigurations of power in the Global South.

\section{Metabolic Rift and the Dialectics of Ecological Crisis}

Contemporary neoliberal approaches to the management of environmental problems posit that problems like the excessive production and emission of greenhouse gases can be addressed by assessing 'natural limits,' and constructing market mechanisms to rationally distribute access to environmental goods, rights to pollute, and rights to make use of 'ecosystem services,' such as carbon sinks (e.g. Tietenberg, 2006; Michaelowa \& Dutschke, 2000; Stowell, 2005; Yamin, 2005).

Efforts by Foster and his colleagues (Foster, 1999; Foster \& Clark, 2009; Foster et al., 2010), however, emphasize the inherently unpredictable and dialectical nature of the way in which human productive activities impact upon the non-human natural environment, and how natural systems respond by shaping human productive systems in unforeseen ways. These theorists argue that, due to the pace of commodification and extraction of raw materials under conditions of capitalist expansion, and due to the great distances which raw materials, food resources and waste travel in the ever-expanding circuits of capitalist economic organization, human interchange with the natural environment under the conditions of capitalism results in significant disruptions to natural ecosystems systems and biogeochemical cycles.

This is a dynamic which Marx himself theorized, most significantly in his writings on nutrient loss and soil exhaustion in Europe in the mid-1880s (Foster, 1999). As Foster explains, Marx conceptualized continuities and disruptions in the interchange between human modes of production and natural systems through his adoption of the concept of 'metabolism' (Stoffwechsel), originally developed by the German agro-chemist Liebig in 1840. Marx appropriated Liebig's concept in his writings in Capital in order to describe the rise of 'an irreparable rift in the interdependent process of social metabolism' under conditions of capitalist production and urban-rural organization (Marx, 1981, p. 949). Using this concept, Marx identified the rift brought about by urbanization, and by agricultural and trade practices that despoil the earth without replenishing its resources, thereby robbing whole regions of their natural conditions of (re)production (Gimenez, 2001). Recently, studies have begun to apply Marx's theory of metabolic rift to contemporary environmental problems, such as the fertilizer treadmill, ocean acidification and climate change (Clark \& York, 2005; Clausen \& Clark, 2005; Mancus, 2007; Clark \& Foster, 2009).

Foster and Clark (2009) and Foster et al. (2010) reject the supposition that the preservation of nature can go hand in hand with the unlimited accumulation of capital, the 'sustained economic growth' (UNCED, 2012, p. 9) that is at the heart of contemporary commitment to 'sustainable development' and the development of a 'green' capitalist economy. Foster and his colleagues maintain that such approaches present a distorted account, advocating economic growth, but seeing wealth entirely in terms of value generated through exchange. As Foster and Clark (2009) and Foster et al. (2010) point out, new 'green' fixes must create new profit opportunities in order to work. The main aim of market-based approaches to climate change is to 'internalize' more and 
more climate change costs, in an attempt to 'get prices right'. But, because scarcity increases exchange value on the market, the destruction of the environment and the commodification of new natural 'goods' (like carbon sinks) will inevitably increase profit opportunities for some at the expense of others.

Foster and his colleagues argue that such attempted fixes always entail negative environmental 'externalities': unintended problems and spillover effects caused by the economic activity they allow or promote (Foster, 2012). While proponents of 'sustainable development' and 'green economy' approaches maintain that profit-making itself should not be seen as a problem, the argument put forward by Foster and his colleagues is that this profit making is always dependent on externalizing costs and 'dumping' these onto nature and weaker members of society, as Gilbertson's (2009) example of a CDM biomass power generation project in Thailand, briefly discussed above, illustrates. While ecological crises may precipitate hardship and suffering for some populations, they will afford opportunities for profit-making for those with the strategic resources and foresight to turn moments of crisis to their own advantage.

In summary, the metabolic rift approach enables us to see the fundamental conflicts between capitalism and environment sustainability. As Magdoff and Foster (2010) outline, capitalism is a system that must continually expand, in constant search for new sources of raw materials, cheaper labor, and new markets. But a system, they argue (ibid.), that, by its very nature, must grow and expand will eventually come up against the reality of finite natural resources. Inevitably, this expansionist strategy results in winners and losers, with clear implications for global social and environmental justice.

\section{Capitalism as 'World-Ecology'}

Moore (2011a, p.1)) suggests that, despite the fact that the theory of metabolic rift is amongst the most dynamic perspectives in critical environmental studies today, it does not go far enough. Moore takes a 'use and transcend' approach, taking the metabolic rift theory as 'an indispensable point of departure in building a unified theory of capitalist development - one that views the accumulation of capital, the pursuit of power, and the production of nature as differentiated moments within the singularity of historical capitalism'. However, according to Moore (2011a, p. 14), the propositions presented by Foster et al. (2010) are grounded in 'a Cartesian binary that locates biophysical crises in one box, and accumulation crises in another'. This means that biophysical problems are seen as consequences of capitalist development, but not constitutive of capitalism as a historical system.

Moore's writings on 'capitalism as world-ecology' represent a recent effort to incorporate the theoretical insights of Marxists writers such as Foster and his colleagues into a more properly historical account of the development of the global capitalist economy. Giving the ecological dimension of production and accumulation a central place, Moore conceives the modern world-system as having developed over the last few centuries through a successive series of crises, and through the subsequent establishment of new modes accumulation, expansion and 'global ecological fix' (Moore 2011b, p. 115). In his view, 'capitalism does not develop upon global nature as much as it emerges through the messy and contingent relations of humans with the rest of nature' (2011b, p. 111). The capitalist world-system is thus conceptualized as constituting an ever-changing global 'world-ecology' or sequence of 'ecological regimes' (Moore, 2010, 2011a, 2011b). Adopting Arrighi's (1994) world-historical perspective, Moore (2011b, p. 114) conceives of historical systems as emerging by means of successive configurations of nature-society relations. Taking capitalism as a matrix of human and extra-human nature, premised on endless commodification, no 
domain of human experience is exempt from socio-ecological analysis. The world-ecological perspective seeks to illuminate what is often invisible in environmental studies, by perceiving 'financialization, industrialization, imperialism (old and new) and commercialization, among many others, as socio-ecological projects'.

Following Marxist theories of value, and in dialogue with Harvey's $(2003,2006)$ work, introduced below, Moore (2010, 2011a, 2011b) explains how the geographical expansion and the temporal acceleration of the extraction of use-value proceeds at the cost of destabilizing the very webs of metabolic relations necessary to sustain the very value production that underpins a socioecological regime in the first place. Thus socio-ecological disruption and innovation have characterized capitalism since its origins, driving capitalism's long history of successive regimes of accumulation, punctuated by periodic industrial and agricultural crises and 'world-ecological revolutions'; these various productive transformations have proceeded through waves of dramatic expansion of opportunities for the appropriation of human and extra-human nature.

Moore (2010) argues that the contemporary neoliberal era has a problem in this regard, however. It has been unable to revolutionize productivity, or to significantly expand access to inexpensive new flows of natural resources, as ecological regimes of the past had done (early capitalism, for example, with its scientific revolution; the $19^{\text {th }}$ century's 'new imperialism'; or the post-World War II, America-led 'golden age'). It has only managed to secure a relatively stable regime of accumulation by facilitating an immense redistribution from poor to rich, through flows of capital around the globe, and through temporal deferments made possible by new forms of financialization. It has been unable, however, to significantly intensify its material base, resulting in secular trends of consistently rising costs for food, energy and raw materials. Hence, for Moore, contemporary neoliberal capitalism urgently needs to devise new opportunities for the appropriation of surplus value, and new forms of commodification of nature are shaped by this imperative. Carbon markets can be seen as serving precisely this kind function within the current global system.

Although Moore provides a nuanced perspective on the historical development of successive capitalist ecological regimes, his treatment of 'geographical restructuring' in the current era is significantly under-theorized. Here, however, recent contributions by Harvey $(2003,2006)$ regarding general processes of capital accumulation, social struggle and environmental transformation can provide key insights.

\section{Uneven Development and Accumulation by Dispossession}

Harvey (2006) considers the workings of capital accumulation, and its effects on the web of socioecological life, as it re-shapes and disturbs eco-systemic processes in the specific locations where they actually take place. Harvey articulates three dimensions of processes of uneven development: capital accumulation in space and time; the associated political, social and class struggles which unfold at a variety of geographical scales; and the key role played by 'accumulation by dispossession' in these processes.

The notion of 'accumulation by dispossession' was developed by Harvey (2003) to account for the particular mechanisms, implemented under the neoliberal phase of capitalism, which have facilitated the transference of assets and the redistribution of wealth and income, either from the mass of the population towards the upper classes, or from vulnerable to rich countries. Accumulation by dispossession constitutes the contemporary functional equivalent of 'primitive' or 'original' accumulation described by Marx in his analysis of the rise of capitalism (Marx, 1976; see also De Angelis, 2007). Although some of the concrete mechanisms are different in the contemporary context, the logic of accumulation remains the same as in the early days of 'primitive accumulation': 
capital has to continuously extend its powers by searching for new territories, sectors and domains, which hitherto have not been incorporated into its circulation. Contemporary forms of accumulation by dispossession include: the commodification and privatization of land and the forceful expulsion of populations; conversion of various forms of property rights; suppression of rights to the commons; commodification of labor power and the suppression of alternative (indigenous) forms of production and consumption; colonial, neo-colonial and imperial processes of appropriation of assets, including natural resources; monetization of exchange and taxation, particularly of land; the slave trade, which continues particularly in the sex industry and in the clandestine use of immigrant labor; and financialization, including the uses and misuses of the expansion of national debt and the credit system (Harvey, 2003).

Accumulation by dispossession provides new frontiers for the penetration of capital, allowing it to overcome recurrent crises of over-accumulation. It is also connected to the emergence of struggles over access to land and living space, and to fundamental resources such as water, biomass, and energy. The use of the notion of space by Harvey facilitates understanding of how and why different places are penetrated in different ways in the process of capital expansion. It also helps to explain how, in an era defined by the global flux of capital, territory remains a central category. The notion of uneven development (Harvey, 2006) facilitates the recognition that exploitative capitalist practices, backed by the political, military and geopolitical activities of the most powerful nation-states, or, in more general terms, by core countries within the world-system, deserve more detailed analysis.

Harvey's approach describes the unevenness of capital accumulation and the different perverse impacts that its unequal distribution has on different countries. However, his formulation provides few indications of how these mechanisms operate in different parts of the global economy. The same can be said about Moore's world-ecological perspective and Foster's metabolic rift approach. These theories, especially in joint articulation, can help to elucidate capitalist processes at a global scale. However, they do not sufficiently describe how these processes operate within particular nations or at the level of relations between nations, particularly in the Global South. Hence, we turn next to the work of Marini, in particular, to his concept of 'sub-imperialism,' for insight into shifting relations of power, uneven development, and ecological dispossession in the South.

\section{Sub-Imperialism: The Contribution of Marxist Dependency Theory}

Marini's $(1972,1977)$ concept of 'sub-imperialism' which he developed as part of a broader Marxist form of dependency theory in the 1970s, can be adapted to help explain the rationale behind the recent embrace of carbon markets by particular nations and fractions of capital, and more specifically, to locate the central role of 'emerging economies' in promoting the global expansion of these policy tools.

In Dialectics of Dependency (2005), Marini elaborates on the interconnected dimensions of dependency: the subordination of some independent nations to another group of core industrialized countries in such a way that the relations of production in the subordinate nations serve to perpetuate their own dependency. This leads to the over-exploitation of workers in those dependent nations, as well as an over-reliance on exports - often of agricultural monocultures and raw commodities - which often entail grave forms of environmental degradation. It also leads to what Marini calls 'sub-imperialism' within the South (Marini, 1972, 1977, 2005; Downey et al., 2010; Rice, 2009). Marini (1972, p. 15) defines 'sub-imperialism' as 'the form which dependent capitalism assumes upon reaching a stage of monopolies and finance capital'. It is a historical process in which dependent economies with a certain level of industrialization and financial capital implement relatively expansionist policies in order to 
secure access to markets and raw materials in other peripheral nations, as well as to export capital to other countries of the periphery. Their position allows these countries to exploit other peripheral markets, in order to try to overcome the contradictions of their own dependent economies, which derive from their relation to the 'core' countries of the capitalist system.

Marini $(1972,1977)$ developed his theory with direct reference to the Brazilian case in the 1970s, a time in which the country was expanding its political and economic influence over South America and Africa in order to secure access to markets and raw materials. Brazil's external policy became known as 'antagonistic cooperation' (the coexistence of collaborative links with the USA and the implementation of geopolitical strategies to gain advantages vis-à-vis the US hegemony), a policy which clearly remains in place in Brazil today, and which seems to have been adopted by other BRICS ${ }^{1}$ countries as well. This is confirmed by Moyo and Yeros (2011) who criticize Harvey's analysis, discussed above, for not distinguishing the specific role of the periphery within process of accumulation as a whole. According to them, while primitive accumulation has always occurred at the center of the system, it has been more intense and continuous in the periphery, even in the countries which have undergone some level of industrialization. For Marini (1977), the continuous pursuit of high levels of primitive accumulation means that conditions of dependency are not overcome in these countries, since the transference of value to the 'core' countries remains a central feature of their insertion into the world economy.

It is important to recognize that Marini's definition of sub-imperialism was originally elaborated in the context of the 1960s and early 1970s. Obviously, the global economic system and international division of labor have advanced and changed since then. However, Marini's theories are particularly pertinent today, because since the early 2000s a newly consolidated bloc of national capitalists in semi-peripheral countries like Brazil, China, Russia and India have, in articulation with transnational classes, developed a renewed interest in accessing raw materials, land for intensified agricultural production, and (often highly polluting) industrial productive facilities in external, peripheral markets. In facilitating these new strategies, the state, which has been pursuing a set of policies and credit lines designed to support the export of capital in the form of outward direct investments, has been decisive (see, for example, Bueno \& Seabra, 2009 on the Brazilian case). What has changed today, is that the rationale for sub-imperialism is no longer the limitations to the realization of profits due to a weak internal market (the sphere of consumption and circulation), but rather restrictions on opportunities for new investments within the internal market. Despite these differences, the sub-imperialist drive has remained the same: while domestic capital continues to invest heavily in extractive and monocultural industries at home, it is increasingly searching for investment opportunities in other peripheral markets as well, precipitating processes of accumulation by dispossession within their broader spheres of influence. This mode of development can be observed in many semi-peripheral nations, particularly in the 'BRICS' countries. China's extensive investment in African arable land and extractive industries in recent years has been well documented (Dent, 2010). What is perhaps less well recognized in the development literature, however, is the extent to which financing from carbon markets like the CDM is now being leveraged by elites from these BRICS countries, to help underwrite these forms of sub-imperialist expansion, a process we will explore in more detail below.

\section{Synthesis: An Emerging Marxist Framework for Understanding Carbon Markets}

While we recognize that the discussion of the four Marxist approaches presented above has been all too brief, our effort has been to begin to build a coherent framework for understanding the role 
of carbon markets within current modes of accumulation of capital and production of nature. We favor a joint articulation of these approaches, as together they are able to provide a historicodialectical frame that generates a wider understanding of the relations between capitalism and nature and the manifestation of this relationship in concrete places.

In our view, the Marxist perspectives discussed above put forward a critique of 'sustainable development' and the 'green economy' approaches advocated at the recent 'Rio+20' summit, which reaffirmed the role of carbon markets and other market mechanisms in capitalism's current efforts to reorganize itself. Carbon markets have not only created a stimulus for practices which can be promoted as environmentally sustainable, but, because they have fostered new economic opportunities for corporations and the finance industry, they have been embraced by powerful economic players. The growing acceptance of these new tools of environmental governance by such powerful actors has inspired relatively optimistic analyses about the possibility that capitalism might manage to transform itself, and that industrial society might, as a result, be successfully 'decarbonized' (e.g. Newell \& Paterson, 2010).

The insights of the Marxist theorists we review here, however, undermine the basic supposition that nature can be sustainably managed as an unlimited resource, in order to support constant economic growth. Even if carbon markets might, eventually, be able to decarbonize the economy (and from today's vantage point, the likelihood that they will succeed in this regard seems bleak), the analyses provided by theorists like Foster, Moore, Harvey and Marini suggest that there will always be negative environmental effects and adverse social implications. From this perspective, carbon markets can be seen as the latest incarnation of an ongoing process of commodification and capitalist expansion, and hence the most recent development in the continuous attempt to find new opportunities for accumulation through, and from, nature. That is, carbon markets are just one more feature within ongoing processes of crisis management, displacement and the perpetual reformation of global capitalism, and have to be understood as part of a long history of re-organization in the continuous pursuit of capital accumulation (Bueno \& Seabra, 2009).

From a Marxist standpoint, carbon markets can be understood as a successful strategy for the creation of a new environmental commodity, introducing a new mechanism of capitalist legitimation and playing a crucial role in the creation of accumulation opportunities, often through new forms of dispossession. In this respect, it is useful to consider the distinction between real and proxy commodification (Castree, 2003, p. 285). Real environmental commodification refers to situations where non-human nature is treated as if it was a 'true' commodity, such as in the case of mining. Proxy commodification, in contrast, involves 'artificially' commodifying a currently noncommodified entity or set of entities; it is about 'compensating for missing markets' and expanding accumulation frontiers. Carbon markets can be seen as an example of proxy commodification, providing new opportunities for allegedly 'green' accumulation (for example, profits made through carbon trading, or the procurement of financing for 'clean' development projects). Bumpus and Liverman (2008), for example, analyze the process of 'decarbonization' as effecting a redistribution of wealth through carbon offset markets, in which the 'rights to emit carbon....and carbon reductions... become commodified and privatized, traded with transaction fees, and allocated and regulated by international and state institutions under conditions of unequal exchange between developed and developing countries' (Bumpus and Liverman, 2008, p. 142).

Yet, carbon markets also have important repercussions in terms of differential access of populations to 'true' commodities such as land, water, minerals and food. In articulation with other, ongoing processes of dispossession and uneven development, carbon markets contribute to some perverse social, economic and environmental trends unfolding within the current regime of capitalist accumulation. Harvey's $(2003,2005,2006)$ work on contemporary forms of 'accumulation by 
dispossession' allows us to begin to consider how these phenomena manifest themselves in different places. This is a very important aspect of any Marxist analytical frame: commodification has to be studied in concrete situations, analyzing the material embeddedness of accumulation processes in the web of socio-ecological life, and considering their detailed effects on particular territories and populations. This is precisely the aim of the many carbon market cases presented in Böhm and Dabhi (2009) that engage with the concrete impacts of so-called 'clean development' projects in Southern countries. The CDM biomass power generation project in Thailand, for example, which we briefly introduced above (Gilbertson 2009), can be seen as a clear example of this process. The local population is dispossessed of its resources and way of life through the introduction of the CDM biomass factory, creating a chain of negative economic, environmental and social implications. Such processes have begun to be widely documented in the literature (e.g. Bond, 2007; Böhm and Dabhi, 2009; Gilbertson \& Reyes, 2009; Lohmann, 2006; Bachram, 2004; Bäckstrand and Lövbrand, 2006; Whiteman et al., 2010).

These existing critiques sometimes give the impression, however, that the North has been dictating climate change policy to a 'helpless' South. As recent climate change negotiations have shown, however, nothing could be further from the truth. What we see, instead, are Southern elites - particularly those in the BRICS countries - pushing for the extension of carbon markets. Given Marini's insights into the pressures driving sub-imperialism within the periphery of the world-economy, it is not at all surprising that the development of the CDM, as well as VOM projects, is dominated by the BRICS countries today (Ganguly \& Bandyopadhyay, 2011). More than 70\% of all those CDM projects that have been registered so far, for example, are located in Brazil, China and India (UNFCCC, 2012). As contributions to Böhm and Dabhi (2009) show, many of these CDM and VOM projects (all put forward as climate change mitigation projects) involve the development of big industrial plants; these plants have significant negative effects on local communities and ecosystems in the South that are situated in close proximity to them. And of course, these plants are owned by Southern elites, who are benefiting financially by selling carbon credits to polluters in the most developed industrial countries. As Lohmann puts it, 'heavy polluters and local corporate "bad citizens," such as India's Tata Group, ITC, Birla, and Jindal, Korea's Hu-Chems Fine Chemical, Brazil's Votorantim and South Africa's Mondi and Sasol, become stars of heroic green narratives,' while villagers and local communities continue to see their local livelihoods and environments destroyed by these heavy-weight industrial companies (Lohmann, 2008a, p. 364). This 'green' façade is supported by national governmental agencies in these countries, such as the DNAs. While these agencies are meant to monitor CDM projects and ensure that local sustainable development goals are achieved, the DNAs are instead run like pro-business agencies that see the CDM projects as welcome economic development and as opportunities to enhance the profits of domestic firms (Gilbertson, 2009; Cabello, 2009).

Elite social groups in the BRICS countries have an inherent interest in expanding carbon markets, because they profit directly from them, without having to feel any of the pain of climate change mitigation themselves. Newell and Paterson (2010) welcome this aspect of the broadening global support for carbon markets. In their view, these kinds of financial incentives - which attract powerful economic and political groups to the cause of climate change mitigation - will help capitalism to decarbonize itself and hence avoid the climate change abyss. We are, however, less convinced that much is to be celebrated in the way that capitalism has embraced carbon markets. We see these tools as essentially providing new profit opportunities for elite actors, by financializing a new commodity (essentially air) in the form of 'carbon allowances' and 'carbon credits.' These commodification processes are, in turn, facilitating processes of dispossession, uneven development and sub-imperialism in the South, while simultaneously exacerbating ecological degradation 
and unsustainable, crisis-prone development paths in many of the localities in which the new 'clean development' projects are based.

\section{Conclusions}

The aim of this paper has been to argue for the value of a Marxist critique of carbon markets, which positions these politico-economic tools within the broader history of global capitalist development and its relation to nature. While some authors see carbon markets as the manifestation of a new phase of 'greener' and more sustainable capitalism (Michaelowa \& Dutschke, 2000; Stowell, 2005; Yamin, 2005), we see these emerging politico-economic tools as part of a historically continuous process. Discussing the work of Marxists such as Foster, Moore, Harvey and Marini, we have shown that carbon markets are best understood as part of a trajectory of capitalist dynamics structuring human relations to the natural environment in specific ways, while producing and re-producing processes of inequality within and between countries.

We argue that carbon markets correspond to, and manifest the logic of, capitalism in its historical development, a logic driven by the need for constant expansion of opportunities for capital accumulation. These specific markets indicate both the creativity and continuity of capitalist development. They are creative in the sense that they create new goods to be traded in the new markets which these policy innovations bring to life. The CDM, for example, is an immensely innovative tool, allowing the commodification of carbon emissions and their trade across the globe. However, carbon markets are also continuous with previous forms of commodification and capitalist expansion in the sense that they, 1) exacerbate preexisting inequalities, through the unequal distribution of new carbon commodities, enhancing opportunities for capital accumulation by some as opposed to others, 2) subsidize environmentally destructive ecological activities (like dams and the use of chemical fertilizers, mentioned above), and, 3) distribute exposure to the negative ecological effects of productive activities unevenly, through processes of dispossession and uneven development. Thus, while those designing and benefiting from carbon markets may perceive them to be successful ecological 'fixes,' populations suffering the consequences of negative externalities (including climate change) are materially and politically disempowered, and find it increasingly difficult to respond in politically meaningful ways.

In this way the politico-economic dynamics of carbon markets are not really new. What Marxists have been arguing for a few decades now is that capitalism, as a socio-ecological system, involves unequal forms of global development; these uneven forms of development often constitute creative new 'neo-colonial' practices, which dispossess people in so-called developing countries, while elites, especially powerful elites of the Global North, enrich themselves. There is sufficient evidence in the existing literature that shows that the 'green' development solutions being financed through carbon markets such as the CDM, which are allegedly being explicitly designed to further sustainable development goals, are, instead, perpetuating this capitalist pathology. This is in line with Banerjee's $(2003,2008)$ exploration of the contradictions inherent in the idea of 'sustainable development.' He argues that, despite claims of a paradigm shift towards a 'greener' and more equitable capitalism, the sustainable development paradigm is ultimately based on an economic, rather than an ecological, rationality, which entails, as a result, very concrete negative outcomes, particularly for the environment and for non-elite groups, such as indigenous people, peasants, subsistence farming communities and workers.

To distinguish the specific roles played by different countries in the contemporary development of capitalism, we have argued that it is of particular importance to understand the central place of 'emerging economies,' such as the BRICS countries, in the politics of carbon markets. Uneven 
processes of development within the South can be increasingly observed, driven by exploitative strategies within the periphery. To fully comprehend this development, we need to adopt a theoretical framework which can comprehend the evolving role of nation states within the international division of labor. The Marxist theory of dependency, which looks at the roles played by different countries in the international division of labor (e.g. Moyo \& Yeros, 2005, 2011), has already explained why these Southern economies have become export-oriented and hence dependent on the Global North. The contribution of an application of Marini's theories of sub-imperialism to current developments in the South, is to elucidate the impossibility of sustainable or 'green' development for these Southern countries, given their particular embeddedness in the international division of labor. While the BRICS articulation might give us a sense of the emergence of some of these countries as increasingly important to the global economy, we have argued that it is mostly the elites of these nations that profit from carbon markets, in the same way that they profit from other commodity-based export strategies (Haque, 1999). Huge sections of the population as a whole, however - in the BRIC countries, in the periphery of the global economy, and increasingly, within the core industrial economies themselves - remain deprived, impoverished and exploited, while the environment continues to be degraded and appropriated for the purpose of accumulation gains (Rice, 2009). Carbon markets might wear 'green' clothes, but the realities on the ground in the Global South suggest that they are anything but 'green' in practice.

Many authors, including Newell and Paterson (2010), have expressed the hope that capitalism might be able to decarbonize and 'green' itself, effecting a dramatic transformation of its own business practices. Maybe they will be proven right; perhaps carbon markets will be able to achieve some degree of decarbonization of the global economy - although the signs are currently not propitious. The main aim of this paper has been, however, to discuss the contradictions, as well as economic, social and economic costs associated with the particular 'decarbonization' strategies being implemented through carbon markets. We have argued that carbon markets, rather than transforming capitalism, are reproducing and deepening unequal relations between North and South, and benefiting Northern and Southern elites while perpetuating uneven development and dispossessing non-elites.

\section{Funding}

This research received no specific grant from any funding agency in the public, commercial or not-for-profit sectors.

\section{Acknowledgement}

We would like to thank Tamra Gilbertson, Larry Lohmann and Oscar Reyes as well as the special issue editors and three anonymous reviewers for their extensive engagement, feedback and comments, all of which have helped tremendously to improve this paper. All mistakes and omissions are, of course, ours alone.

\section{Note}

1. BRICS stands for Brazil, Russia, India, China and South Africa. Politicians from the BRICS countries meet irregularly to define common politico-economic strategies, setting a counter point to the 'international community' led by the 'developed' Northern countries. The acronym BRIC was created by Jim O’Neill - Goldman Sachs Chief Economist. In April 2011 South Africa was included in the group.

\section{References}

Abate, R. S. (2005). Kyoto or not, here we come: The promise and perils of the piecemeal approach to climate change regulation in the United States. Cornell Journal of Law and Public Policy, 15, 369-401.

Arrighi, G. (1994). The long twentieth century: money, power and the origins of our time. London: Verso. 
Bachram, H. (2004). Climate fraud and carbon colonialism: The new trade in greenhouse gases. Capitalism Nature Socialism, 15(4), 1-16.

Bäckstrand, K., \& Lövbrand, E. (2006). Planting trees to mitigate climate change: Contested discourses of ecological modernization, green governmentality and civic environmentalism. Global Environmental Politics, 6(1), 50-75.

Banerjee, S. B. (2003). Who sustains whose development? Sustainable development and the reinvention of nature. Organization Studies, 24, 143-180.

Banerjee, S. B. (2008). Necrocapitalism. Organization Studies, 29, 1541-1563.

Bernstein, S. (2002). The compromise of liberal environmentalism. New York: Columbia University Press.

Bloomberg New Energy Finance (2010). Building bridges: State of the voluntary carbon markets. Retrieved from http://bnef.com/WhitePapers/download/28.

Böhm, S., \& Dabhi, S. (Eds.) (2009). Upsetting the offset: the political economy of carbon markets. London: Mayfly. Retrieved from http://mayflybooks.org/?page_id=21.

Böhm, S., \& Dabhi, S. (2011). Fault lines in climate policy: What role for carbon markets? Climate Policy, $11,1389-1392$.

Bond, P. (2007). South African subimperialism. Paper presented to the Conference Toward an Africa Without Borders, Durban University of Technology, 8 July 2007.

Bruno, K., \& Karliner, J. (2002). Earthsummit.Biz: the corporate take-over of sustainable development. Oakland, CA: Food First Books.

Bueno, F. M., \& Seabra, R. L. A. (2009). Teoría do Subimperialismo Brasileiro: Notas para uma (Re)Discussão Contemporânea. Paper presented to the $6^{\circ}$ Colóquio Internacional Marx e Engels, 3-6 November.

Bumpus, A. G., \& Liverman, D. M. (2008). Accumulation by decarbonization and the governance of carbon offsets. Economic Geography, 84, 127-155.

Cabello, J. (2009). The politics of the Clean Development Mechanism: Hiding capitalism under the green rug. In S. Böhm and S. Dabhi (Eds.), Upsetting the offset: The political economy of carbon markets (pp. 192-202). London: Mayfly. Retrieved from http://mayflybooks.org/?page_id=21.

Carbon Trade Watch (2011). EU Emissions Trading System: Failing at the third attempt. Retrieved from http://www.carbontradewatch.org/articles/eu-emissions-trading-system-failing-at-the-third-at.html.

Castree, N. (2003). Commodifying nature? Progress in Human Geography, 27, 272-297.

Chatterjee, P., \& Finger, M. (1994). The earth brokers: power, politics and world development. London: Routledge.

Clark, B., \& Foster, J. B. (2009). Ecological imperialism and the global metabolic rift: Unequal exchange and the guano/nitrates trade. International Journal of Comparative Sociology, 50, 311-334.

Clark, B., \& York, R. (2005). Carbon metabolism: Global capitalism, climate change, and the biospheric rift. Theory \& Society, 34, 391-428.

Clausen, R., \& Clark, B. (2005). The metabolic rift and marine ecology: An analysis of the oceanic crisis within capitalist production. Organization \& Environment, 18, 422-444.

ClimateCare (2011). Carbon Calculator. Retrieved from http://www.climatecare.com/landrover.

Dale, G. (2008). 'Green shift': An analysis of corporate responses to climate change. International Journal of Management Concepts and Philosophy, 3(2), 134-155.

De Angelis, M. (2007). The beginning of history: value struggles and global capital. London: Pluto Press.

C.M. Dent (Ed.) (2010). China and Africa development relations. London: Taylor \& Francis.

Downey, L., Bonds, E., \& Clark, K. (2010). Natural resource extraction, armed violence, and environmental degradation. Organization \& Environment, 23, 417-445.

Esteva, G. (1987). Regenerating people's space. Alternatives, 12, 125-152.

Fahrenthold, D. A., \& Mufson, S. (2007). Cost of saving the climate meets real-world hurdles. Washington Post, 16 August. Retrieved from www.washingtonpost.com/wp-dyn/content/article/ 2007/08/15/ AR2007081502432.html.

Foster, J. B. (1999). Marx's theory of metabolic rift: Classical foundation for environmental sociology. American Journal of Sociology, 105, 366-405.

Foster, J. B. (2000). Marx's ecology: materialism and nature. New York: Monthly Review Press. 
Foster, J. B. (2002). Ecology against capitalism. New York: Monthly Review Press.

Foster, J. B. (2012). Rio + 20: Here we go again, Amandla! Retrieved from http://www.amandlapublishers. co.za/special-features/the-green-economy/1317-rio--20-here-we-go-again--by-john-bellamy-foster.

Foster, J. B., \& Clark, B. (2009). The paradox of wealth: Capitalism and ecological destruction. Monthly Review 61(6). Retrieved from http://monthlyreview.org/2009/11/01/the-paradox-of-wealth-capitalismand-ecological-destruction.

Foster, J. B., Clark, B., \& York, R. (2010). The ecological rift: capitalism's war with the earth. New York: Monthly Review Press.

Foti, A. (2009). Climate anarchists vs green capitalists. Retrieved from www.zcommunications.org/climateanarchists-vs-green-capitalists-by-alex-foti.

Ganguly, A., \& Bandyopadhyay, A. (2011). The post 2010 carbon market: A focus on the regulated market. Retrieved from www.jwalaindia.org/Amrita\%20ganguly.pdf.

Ghosh, S., \& Sahu, S.K. (Eds.) (2011). The Indian Clean Development Mechanism: subsidizing and legitimizing corporate pollution, an overview of CDM in India with case studies from various sectors. Kolkata: Disha.

Giddens, A. (2009). The politics of climate change. Cambridge, UK: Polity.

Gilbertson, T. (2009). How sustainable are small-scale biomass factories? A case study from Thailand. In S. Böhm and S. Dabhi (Eds.), Upsetting the offset: the political economy of carbon markets (pp. 57-71). London: Mayfly. Retrieved from http://mayflybooks.org/?page id=21.

Gilbertson, T., \& Reyes, O. (2009). Carbon Trading: How it works and why it fails. Critical Currents, no. 7. Uppsala: Dag Hammerskjold Foundation.

Gimenez, M. E. (2001). Does ecology need Marx? Monthly Review, 52(8). Retrieved from http://monthlyreview.org/2001/01/01/does-ecology-need-marx.

Grubb, M., Vrolijk, C., \& Brack, D. (1999). The Kyoto protocol: a guide and assessment. London:Royal Institute of International Affairs Energy and Environmental Programme.

Guha, R. (1988). Ideological trends in Indian environmentalism. Economic and Political Weekly, 24(49), 80-92.

Haque, M. S. (1999). The fate of sustainable development under neo-liberal regimes in developing countries. International Political Science Review, 20, 197-218.

Haque, U. (2011). The new capitalist manifesto. Boston. Harvard Business Review Press.

Harvey, D. (2003). The new imperialism. New York: Oxford University Press.

Harvey, D. (2005). A brief history of neoliberalism. Oxford: Oxford University Press.

Harvey, D. (2006). Spaces of global capitalism: towards a theory of uneven geographical development. London: Verso.

Harvey, D. (2010). The enigma of capital and the crises of capitalism. New York: Oxford University Press.

Heartfield, J. (2008). Green capitalism: manufacturing scarcity in an age of abundance. London: Mute.

Korten, D. (2006). The great turning: from empire to earth community. Bloomfield, CT: Kumarian Press.

Land Rover (2011). Our plan for a sustainable future. Retrieved from www.landrover.com/gb/en/lr/aboutland-rover/sustainability/.

Lohmann, L. (Ed.) (2006). Carbon trading: a critical conversation on climate change, privatisation and power. Uppsala: The Dag Hammarskjöld Foundation.

Lohmann, L. (2008a). Carbon trading, climate justice and the production of ignorance: Ten examples. Development, 51, 359-365. Retrieved from www.thecornerhouse.org.uk/pdf/document/IgnoranceFinal. pdf.

Lohmann, L. (2008b). Hold the applause: A critical look at recent EU climate claims. The Corner House. Retrieved from www.thecornerhouse.org.uk/resource/hold-applause.

Lohmann, L. (2009a). Neoliberalism and the calculable world: The rise of carbon trading. In S. Böhm and S. Dabhi (Eds.), Upsetting the offset: the political economy of carbon markets (pp. 25-37). London: Mayfly. Retrieved from http://mayflybooks.org/?page_id=21.

Lohmann, L. (2009b). Toward a different debate in environmental accounting: The cases of carbon and costbenefit. Accounting, Organizations and Society, 34, 499-534. 
Lohmann, L. (2009c). Climate as investment. Development and Change, 40, 1063-1083.

Lohmann, L. (2010). Uncertainty markets and carbon markets: Variations on Polanyian themes. New Political Economy, 15, 225-254.

Magdoff, F., \& Foster, J. B. (2010). What every environmentalist needs to know about capitalism. Monthly Review, March 2010. Retrieved from http://scienceandsocietyinbob.com/khabor/mar-10/10-3-10What\%20Every\%20Environmentalist\%20Needs\%20to\%20Know \%20About\%20Capitalism.pdf.

Mancus, P. (2007). Nitrogen fertilizer dependency and its contradictions. Rural Sociology, 72, 269-288.

Marini, R. M. (1972). Brazilian subimperialism. Monthly Review, 23(9), 14-24.

Marini, R. M. (1977). La acumulación capitalista mundial y el subimperialismo. Cuadernos Políticos 12. Retrieved from http://www.marini-escritos.unam.mx/006_acumulacion_es.htm.

Marini, R. M. (2005). Dialética da Dependência. In R. Traspadini and J.P. Stedile and (Eds.), Ruy Mauro Marini: Vida e Obra (pp. 137-180). São Paulo: Expressão Popular.

Marx, K. (1976). Capital (Vol. 1). New York: Vintage.

Marx, K. (1981). Capital (Vol. 3). London: Penguin Books.

Marx, K., \& Engels, F. (1964). The Communist manifesto. New York: Monthly Review Press.

Marx, K., \& Engels, F. (1975). Collected works. New York: International Publishers.

Michaelowa, A. (2011). Failures of global carbon markets and CDM? Climate Policy, 11, 839-841.

Michaelowa, A., \& Dutschke, M. (2000). Climate cooperation as development policy: The case of Costa Rica. International Journal of Sustainable Development, 3(1), 63-94.

Misoczky, M. C. (2011). World visions in dispute in contemporary Latin America: Development $\times$ harmonic life. Organization, 18, 345-363.

Moore, J. W. (2010). The end of the road? Agricultural revolutions in the capitalist world-ecology, 1450-2010. Journal of Agrarian Change, 10, 389-413.

Moore, J. W. (2011a). Transcending the metabolic rift: A theory of crises in the capitalist world-ecology. Journal of Peasant Studies, 38(1), 1-46.

Moore, J. W. (2011b). Ecology, capital, and the nature of our times: Accumulation and crisis in the capitalist world-ecology. Journal of World-Systems Research, 17(1), 108-147.

Moyo, S., \& Yeros, P. (2005). The resurgence of rural movements under neoliberalism. In S. Moyo \& P. Yeros (Eds.), Reclaiming the Land: The Resurgence of Rural Movements in Africa, Asia and Latin America. London \& Cape Town: Zed Books \& David Philip.

Moyo, S., \& Yeros, P. (2011). Rethinking the theory of primitive accumulation: Imperialism and the new scramble for land and natural resources. Paper presented to the 2nd IIPPE Conference, 20-22 May.

Mueller, T., \& Passadakis, A. (2008). 20 Theses against green capitalism. Retrieved from http://slash.autonomedia.org/node/11656, accessed 20 June 2009.

Newell, P. (2012). The political economy of carbon markets: The CDM and other stories. Climate Policy, 12, $135-139$.

Newell, P., \& Paterson, M. (2010). Climate capitalism: global warming and the transformation of the global economy. Cambridge, UK: Cambridge University Press.

O'Connor, J. (1988). Capitalism, nature, socialism: A theoretical introduction. Capitalism, Nature, Socialism, $1(1), 11-38$.

O’Connor, J. (1998). Natural causes. New York: Guilford.

Olsen, K. H. (2007). The clean development mechanism's contribution to sustainable development: A review of the literature. Climatic Change, 84(1), 59-73.

Pinkse, J., \& Kolk, A. (2012). Addressing the climate change-sustainable development nexus: The role of multi-stakeholder partnerships. Business and Society, 51, 176-210.

Porter, M. E., \& Kramer, M. R. (2011). The big idea: Creating shared value. Harvard Business Review, Jan-Feb.

Pouchepadass, J. (1995). Colonialism and environment in India: Comparative perspective. Economic and Political Weekly, 30, 2059-2067.

Reuters (2007). Carbon trader windfall profits. Retrieved from http://blogs.reuters.com/blog/2007/08/24/ carbon-trader-windfall-profits. 
Reyes, O. (2011). EU Emissions Trading System: Failing at the third attempt. Carbon Trade Watch briefing paper. Retrieved from www.carbontradewatch.org/downloads/publications/ETS_briefing_april2011.pdf.

Rice, J. (2009). The transnational organization of production and uneven environmental degradation and change in the world economy. International Journal of Comparative Sociology, 50, 215-236.

Schlup, M. (2005). The gold standard, linking the CDM to development and poverty reduction. Presentation at conference on climate or development. Hamburg Institute of International Economics, 28-29 October.

Seres, S. (2008). Analysis of technology transfer in CDM projects. Report for the UNFCCC Registration \& Issuance Unit CDM/SDM, December.

Shiva, V. (2005). Earth democracy: justice, sustainbility, peace. London: Zed Books.

Sirohi, S. (2007). CDM: Is it a 'win-win' strategy for rural poverty alleviation in India? Climatic Change, $84,91-110$.

Smith, K. (2008). 'Offset Standard is Off Target,' Red Pepper, April. Retrieved from www.redpepper.org.uk/ Offset-standard-is-off-target.

Stowell, D. (2005). Climate trading: development of greenhouse gas markets. Basingstoke, UK: Palgrave Macmillan.

Sullivan, S. (2010). 'Ecosystem service commodities' - a new imperial ecology? Implications for animist immanent ecologies, with Deleuze and Guattari. New Formations: A Journal of Culture/Theory/Politics, 69, 111-128.

Sutter, C., \& Parreño, J. C. (2007). Does the current Clean Development Mechanism (CDM) deliver its sustainable development claim? An analysis of officially registered CDM projects. Climatic Change, 84 , 75-90.

Swyngedouw, E. (2010). Apocalypse forever? Post-political populism and the specter of climate change. Theory, Culture \& Society, 27, 213-232.

Tietenberg, T. H. (2006). Emissions trading: principles and practice, 2nd edn. Resources for the Future.

UNCED (United Nations Conference on Environment and Development) (1992). Earth Summit: Agenda 21. The United Nations Programme of Action from Rio (Agenda 21: Programme for Action for Sustainable Development; Rio Declaration on Environment and Development; Statement of Forest Principles) The Final Text of Agreements negotiated by governments at the UNCED, 3-14 June 1992, Rio de Janeiro, Brazil. New York: United Nations Department of Public Information.

UNCED (United Nations Conference on Environment and Development) (2012). The future we want. Rio+20 United Nations Conference on Sustainable Development, Rio de Janeiro, 19 June 2012.

UNFCCC (2010). About CDM. Retrieved from http://cdm.unfccc.int/about/index.html.

UNFCCC (2012). CDM in numbers. Retrieved from http://cdm.unfccc.int/Statistics/index.html.

US Department for Environment (2011a). Retrieved from http://apps3.eere.energy.gov/greenpower/markets/ carbon.shtml?page $=1$ (accessed 21 September 2012).

US Department for Environment (2011b). Retrieved from http://apps3.eere.energy.gov/greenpower/markets/ certificates .shtml?page $=2 \&$ companyid $=746$.

Wara, M. (2007). Is the global carbon market working? Nature, 445, 595-596.

Whiteman, G., Dorsey, M., \& Wittneben, B. (2010). Business and biodiversity: They would say that. Nature, $466,435$.

World Bank (2011). Mobilizing climate finance: A Paper prepared at the request of G20 Finance Ministers. Retrieved from www.g20-g8.com/g8-g20/root/bank_objects/G20_Climate_Finance_report.pdf.

World Commission on Environment and Development (1987). Our common future ('The Brundtland Report'). Oxford: Oxford University Press.

Yamin, F. (Ed.) (2005). Climate change and carbon markets: a handbook of emission reduction mechanisms. London: Earthscan.

\section{Author biographies}

Steffen Böhm is Director of the Essex Sustainability Institute and Professor in Management and Sustainability at the University of Essex, UK. His research focuses on political economies and ecologies of organization, management and the environment. He was a co-founder of ephemera: theory \& politics in organization. He 
is also co-founder and co-editor of the open publishing press MayFlyBooks (www.mayflybooks.org), as well as Interface: A Journal for and about Social Movements (www.interfacejournal.net).

Maria Ceci Misoczky is a professor and researcher in organization studies at the Postgraduate Administration Program at the Federal University of Rio Grande do Sul (Porto Alegre, Brazil). Her research interests include the organization of social struggles, focusing on socio-environmental conflicts and anti-capitalist movements in Latin America. She also coordinates the research group Organization and Liberating Praxis and is the editor-in-chief of REBELA - Revista Brasileira de Estudos Latino-Americanos (Brazilian Journal of Latin American Studies).

Sandra Moog is a lecturer in management and sustainability at Essex Business School, University of Essex. She was co-editor, along with Rob Stones, of Nature, Social Relations and Human Needs: Essays in Honour of Ted Benton (Palgrave, 2009), and has written numerous book chapters and articles about the role of transnational civil society organizations in global environmental governance. She holds degrees in sociology and political science from the University of Chicago and the University of California at Berkeley. 